\title{
The inspection of the triggering mechanism for a hazardous mudflow in an urbanized territory
}

\author{
H. Chen - R. H. Chen · F. C. Yu - W. S. Chen - J. J. Hung
}

\begin{abstract}
On October 16, 1998, a mudflow of $2,000 \mathrm{~m}^{3}$ resulting in five deaths in the Neihu area of Taipei city came in the wake of Typhoon Zebert, which delivered approximately $300 \mathrm{~mm}$ /day of precipitation. The destructive $50-\mathrm{m}$-long mudflow rushed down the hill without any forewarning, wreaking severe destruction to the properties below. Based on in-situ investigation, this paper discusses the event scenario and provides critical data analyses to identify the contributing factors and main triggering mechanism of the disaster. The chances of possible water uplift due to groundwater conditions, the engineering properties of the geomaterials, and the influence of man-made changes in the morphology are examined in weighing the importance of these factors and identifying the main trigger.
\end{abstract}

Keywords Mudflow · Disaster - Geomaterial · Taiwan

Received: 22 September 2003 / Accepted: 10 December 2003 Published online: 17 February 2004

(C) Springer-Verlag 2004

H. Chen $(\square) \cdot$ W. S. Chen

Department of Geosciences, National Taiwan University,

No. 1, Sec. 4, Roosevelt Road, Taipei, Taiwan

E-mail: hchen@ntu.edu.tw

Tel.: +886-02-23636994

Fax: +886-02-23636095

R. H. Chen · J. J. Hung

Department of Civil Engineering, National Taiwan University,

No.1, Sec. 4, Roosevelt Road, Taipei, Taiwan

F. C. Yu

Department of Soil \& Water Conservation,

National Chung Hsing University, 250 Kuo-kwang Road,

402 Taichung, Taiwan

\section{Introduction}

The disaster area, Neihu, is in the northeastern part of Taipei City in northern Taiwan. In October 16, 1998, Typhoon Zebert dumped more than $300 \mathrm{~mm} /$ day of precipitation in this region, causing a hazardous mudflow that resulted in five deaths and damaged three buildings without forewarning (Fig. 1). This funnel-shaped mudflow had a volume of $2,000 \mathrm{~m}^{3}$. A man-made platform and construction stood right at the top of the mudflow. Eyewitnesses to this disaster were deeply concerned because the disaster area occurred in the largest city in Taiwan. Enlisting various methods, this study attempts to identify and explain the triggering mechanism of this mudflow.

A mudflow is a hazardous flow state, consisting of over $50 \%$ fine-grain material of less than $2 \mathrm{~mm}$ (Varnes 1978; Johnson and Rodine 1984). Generally, the geological environment of an in-situ event of this sort will possess certain contributing factors (Leonards 1982; Brunsden 1984), including geomaterial properties, hydraulic features, and slope stability. Thus, this present investigation of the slope's characteristics focuses on the slope geometry, the slope-forming material, and the upper slope influence zone.

Wilson and Wieczorek (1995) and De Vita and Reichenbach (1998) point out that in disaster inspections, the slope stability theory should be complemented with on-site observations of rainfall and mudflow occurrences, together with some plausible assumptions about the slope characteristics and the hillside runoff materials. Such inspections should include various techniques of describing key features of the geology and geomorphology of the study area (Selby 1993; Dai and Lee 2001).

The authors compared the topography of the site across time to elucidate present differences from three earlier periods, using relief maps drawn in 1969, 1980 and 1983. Understandably, slope geometry has an important impact on the runoff behaviour of mudflow material. A detailed field investigation will specify the event explanation by introducing the experimental results of field tests (Cruden and Varnes 1996; Chen and Su 2001).

This discussion of the contributing factors will focus on the demolition of a past human structure before the disaster and note the flow volume from the heavy rainfall together with the remnant parameters of the human structure. 


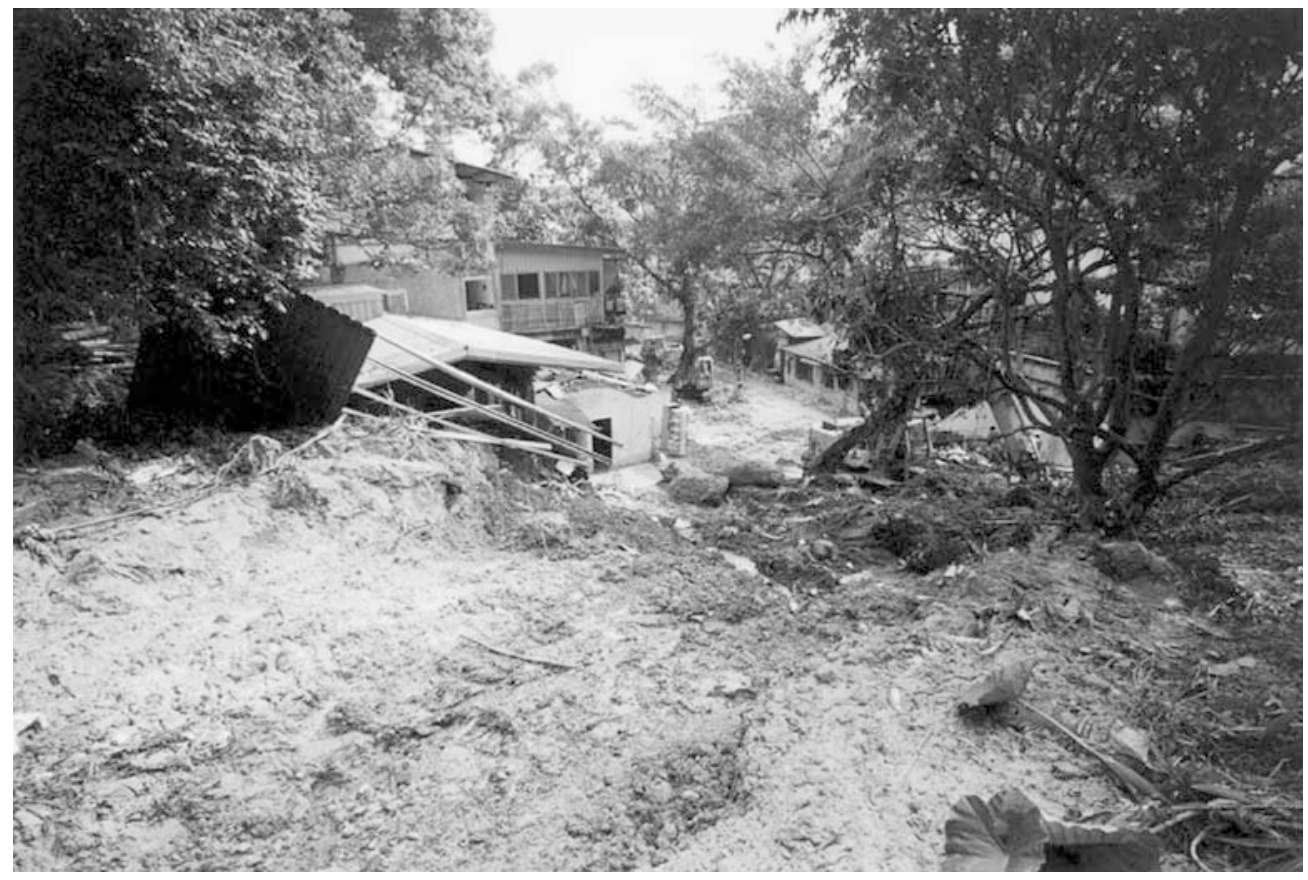

Fig. 1

The hazardous mudflow rapidly flowed down into the community

\section{Site condition}

The hazardous mudflow was funnel-shaped (Fig. 2), open at the upper part of the mudflow to the north and evacuating downward to the south, causing the geohazard. Five buildings stood right at the exit of the funnel shaped flow. A platform of $30 \times 80 \mathrm{~m}$ was distributed at the top of the funnel (Fig. 3). A newly eroded gully was formed along the slope, connecting the entrance to the exit of the mudflow. The dip direction of this gully proceeded from north to south. The width of the gully was around $31 \mathrm{~m}$ at the top and $10 \mathrm{~m}$ in the central part. The length of the mudflow was approximately $60 \mathrm{~m}$. The flow material particles were mostly less than $2 \mathrm{~mm}$ in size and distributed over $80 \%$ of the study area. Various thicknesses of the flow material ranged from 1 to $4 \mathrm{~m}$. The basement of the outcrop was revealed in the central part of the erosion gully after the disaster.

On-site investigation revealed that several layers of moss still appeared on the front of the platform surface after the disaster. Each moss layer was about 5 to $10 \mathrm{~cm}$ in thickness, with some cracks displayed unambiguously beneath the moss. The moss area extended about $50 \mathrm{~m}$ in length and $5 \mathrm{~m}$ in width on the platform. Consequently, it is known that the water or erosion material did not massively pass through this area-for the moss growth clearly had been growing on the edge of the platform for at least 1 year.

The inner edge of the platform had a 5-cm-high embankment along the east and west ends of the platform, which guided the runoff and transported the accumulated water into the western side of the drainage system. The drainage system included a pipe, $50 \mathrm{~cm}$ in diameter, to gather accumulated water and divert it to the southwest. This pipe was set along the slope stairs in the southwest part of the study area.
An open channel $10 \mathrm{~cm}$ in width occupied the north edge of the platform. This open channel was also used to divert the runoff from the upper hill to flow into the drainage system in the southwest part. The purpose of the former drainage design was to gather the surface water and direct it to the southwest end of the platform.

The erosion gully is concave shaped, with a slope gradient ranging from 48 to $80 \%$. The walls of two houses are very close to the bottom of the hill (Fig. 4). The near vertical slope at the bottom of the hill ranges from 3 to $5 \mathrm{~m}$ in height, higher than the basement of the housing construction. Vegetation has been growing next to the erosion gully for a long time. The erosion gully can be traced by the runoff on the study area. The catchments are around $2.17 \mathrm{ha}$, and the elevation of the hilltop is $120 \mathrm{~m}$. The slope gradient ranges from 43 to $52 \%$. Various trees and shrubs cover the whole uphill area. Groundwater was still seeping out from the joints in the middle portion of the erosion gully during the on site inspection.

\section{Geological setting}

The major rock type in the study area is massive sandstone of the Mushan Formation of the early Miocene (Ho 1986). This is mainly quartz sandstone. The thickness of the massive sandstone ranges from $30 \mathrm{~cm}$ to $1 \mathrm{~m}$, consisting of nearly $80 \%$ medium- to coarse-grain quartz. The rock surface is normally yellowish-brown in colour and looks weathered. Mushan sandstone generally weathers into sandy soil on the ground surface. In the erosion gully, massive sandstone is distributed below, while the upper part is sandstone with embedded shale (Fig. 5).

The bedding, which appears in the erosion gully, has a nearly east-west orientation with dip angle ranging from 30 


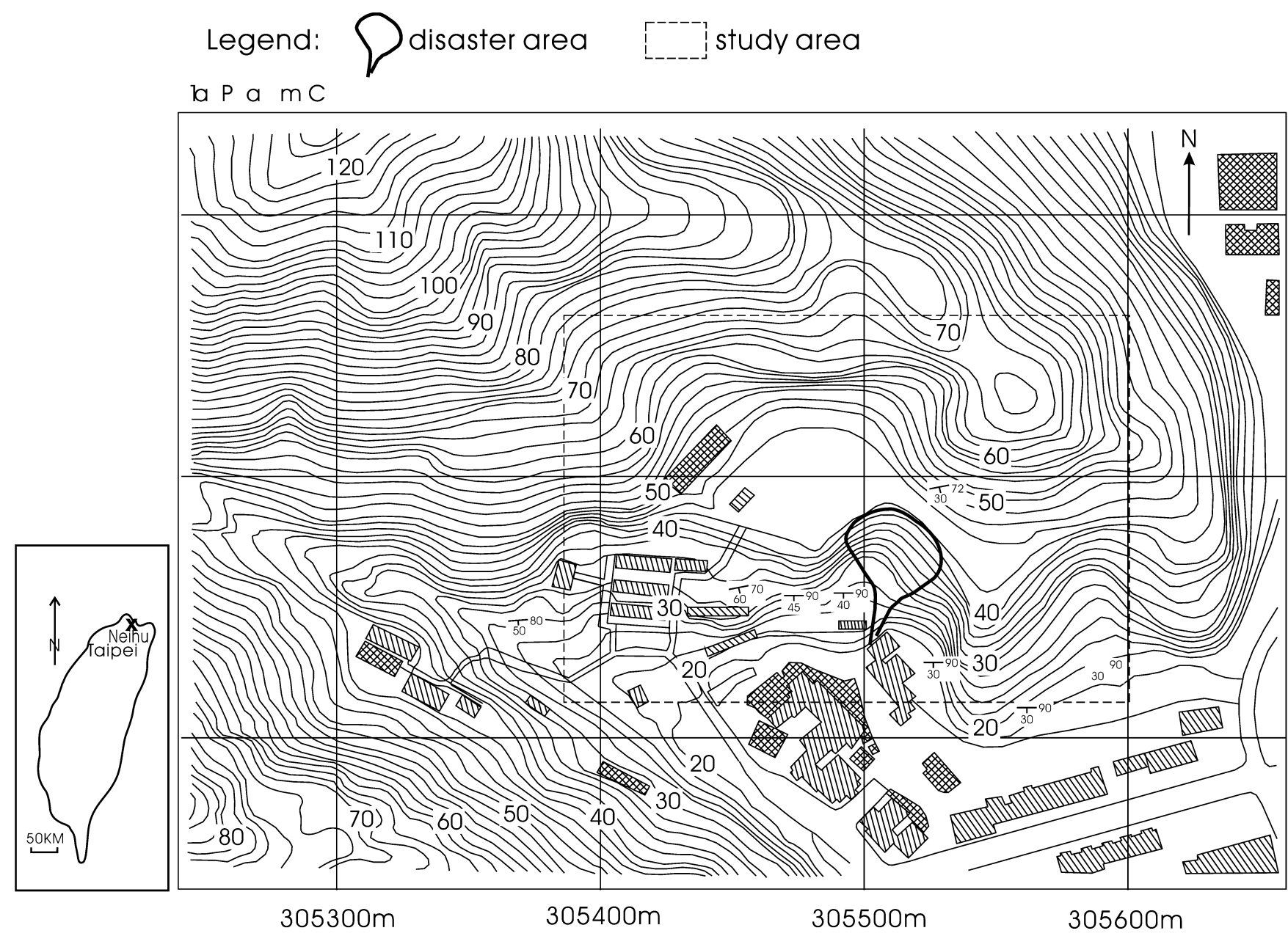

Fig. 2

The location and topography map of the study area

to $60^{\circ}$ toward the south. Only one joint $N 8^{\circ} \mathrm{W}$ is present, dipping $84^{\circ}$ toward the north. The joint orientation roughly parallels the slope surface of the erosion gully. The springs constantly flow from the joint planes in the middle part of the erosion gully. It seems that the joint planes also govern the groundwater channel in the study area.

\section{Morphology change}

Contour maps prepared during three earlier periods-1969, 1980 and 1983-were compared with the present topography. The cross sections show that the platform had been set up before 1980 .

Originally, a military training space, the platform was constructed with debris material approximately $2 \mathrm{~m}$ in thickness by cutting away the ground surface. Debris from the cutting had been dumped directly into the gully below. At the same time an embankment had been set up along the southeast edge of the platform to impede overflow down to the slope and to guide the water into the drainage system. The difference in morphology in the maps shows that the length of the embankment had extended about $50 \mathrm{~m}$ from east to west until 1993.
The 1980 map shows that the former erosion gully of the study area originally was oriented from northwest to southeast. By 1993, the upper parts of the gully had formed a concave shape with decreased elevation. The cross sections show that the thickness range in the middle part of the gully had decreased by $4 \mathrm{~m}$, compared to the periods of 1969 and 1993 (Fig. 6). Moreover, the slope gradient of the erosion gully on the upper part increased from $10^{\circ}$ in 1969 to $30^{\circ}$ in 1993 . On-site investigation revealed that the elevation of the slip surface had remained similar to that of 1980. The sliding debris mentioned above probably was material dumped between 1969 and 1980.

The cross sections also display two steps of slope gradient that are distributed on two different horseshoe-shaped slopes. On the upper step, the slope angle ranges from 15 to $27^{\circ}$ and the lower step ranges from 25 to $27^{\circ}$. In particular, the slope angle at the very bottom of the hill is more than $40^{\circ}$. Figure 7 displays the present topography mode of the disaster area.

\section{Geomaterial properties}

Twelve samples for laboratory tests were taken by statically pressing the tube samplers from the upper, middle, lower sections and the west part of the erosion gully 

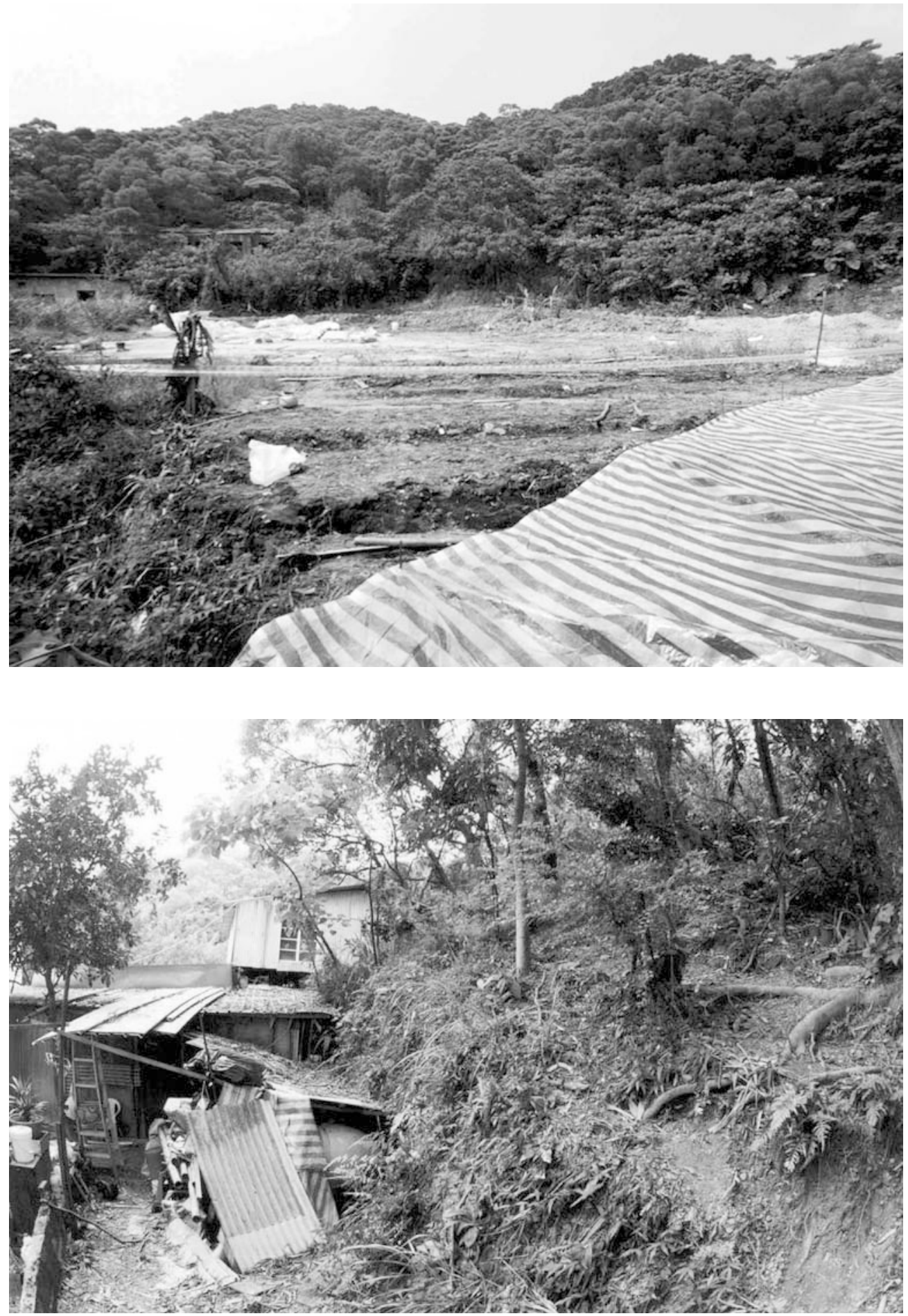

Fig. 3

A platform of $30 \times 80 \mathrm{~m}$ distributed at the top of the funnel shape area. Several moss layers still clearly appear on the front of the platform surface after the disaster
Fig. 4

The walls of the two houses barely touched the foot of the hill
(Fig. 8). Three samples were taken from each part. The purpose of the laboratory tests was to understand the engineering characteristics of the geomaterial in the study area. The results of the tests for engineering properties are shown in Table 1.

Most of the soils belong to silty and clayey sand. The soil was classified as SC and SM according to the Unified Soil Classification System. The void ratio ranges from 0.63 to 0.86 , and the porosity ranges from 39 to $46 \%$. Thus, the soils were in a loose state at the study site.
The shear strength was measured by the consolidated undrained triaxial test on saturated samples. Confining pressure was applied from 0.1 to $0.4 \mathrm{~kg} / \mathrm{cm}^{2}$. In the total stress state, the results of the friction angle range from 24 to $30^{\circ}$, and the cohesion ranges from 0.05 to $0.06 \mathrm{~kg} / \mathrm{cm}^{2}$. In effective stress state, the results of the friction angle ranges from 31 to $32^{\circ}$ and the cohesion ranges from 0.02 to $0.03 \mathrm{~kg} / \mathrm{cm}^{2}$. Therefore, the average values of $c=0.5 \mathrm{~kg} / \mathrm{cm}^{2}, c^{\prime}=0.03 \mathrm{~kg} / \mathrm{cm}^{2}$ and $\emptyset=27^{\circ}, \emptyset^{\prime}=31^{\circ}$ were chosen for the slope stability analysis in this study. 


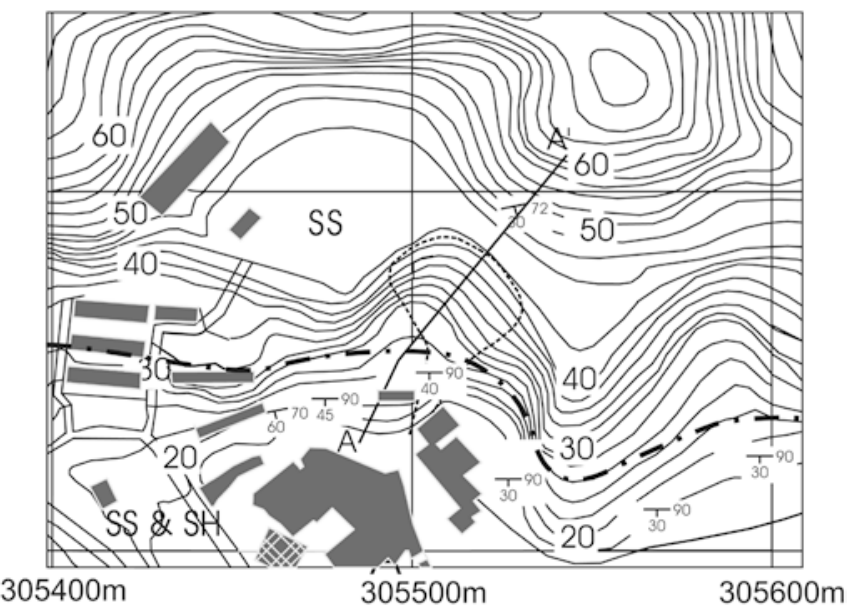

(A) $-40-$ Contour line (2-m interval)

SS Sandstone

SS \& SH Sandstone \& shale interbedded

- - Stratigraphy boundary

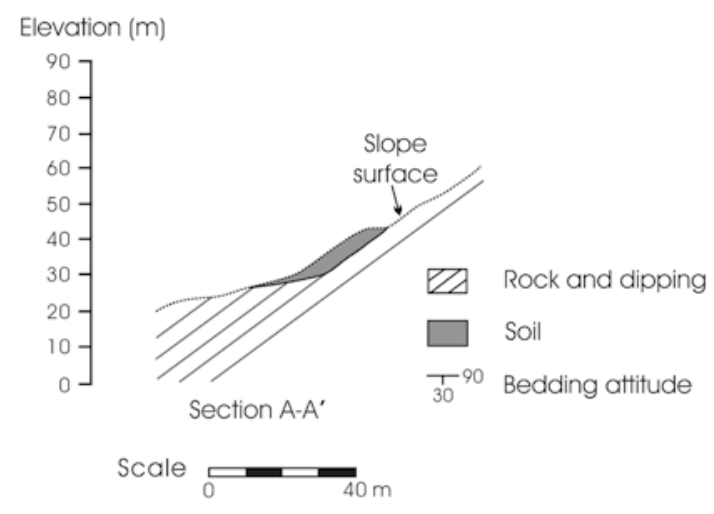

(B)

Fig. 5

The geological map of the study area

For permeability tests, the authors also applied confining pressure ranging from 0.1 to $0.4 \mathrm{~kg} / \mathrm{cm}^{2}$. That was equivalent to the earth pressure from 1.8 to $7.2 \mathrm{~m}$ depth. The results of the coefficient of the permeability range from $2.2 \times 10^{-2}$ to $3.4 \times 10^{-2} \mathrm{~cm} / \mathrm{s}$ in the east part of the gully, and from $2.3 \times 10^{-3}$ to $6.2 \times 10^{-3} \mathrm{~cm} / \mathrm{s}$ in the west part of gully. Thus, both parts on the study area were in a permeable state where the underground surface was from 2 to $7 \mathrm{~m}$.

\section{Hydraulic analysis}

The elevation at the top of the catchments is $120 \mathrm{~m}$, and that of the platform is $42 \mathrm{~m}$. The catchments area is $2.17 \mathrm{ha}$. The flow speed on the slope surface is generally $0.6 \mathrm{~m} / \mathrm{s}$. Hence, water flow would take $200 \mathrm{~s}(\mathrm{t})$ to reach the elevation of $18 \mathrm{~m}$ at the bottom of the slope.

$\mathrm{t}=120 \mathrm{~m} / 0.6 \mathrm{~m} / \mathrm{s}=200 \mathrm{~s}=0.056 \mathrm{~h}$

The disaster area of Neihu lies between two precipitation measure stations. The accumulated precipitation was collected from midnight October 14 to midnight October 17, 1998 when the Zebert typhoon attacked Taipei City.

The total accumulated precipitation was calculated to be $506 \mathrm{~mm}$, thus the average day precipitation was $164 \mathrm{~mm}$ in the city center. The calculated total accumulated precipitation was $921 \mathrm{~mm}$ while the average daily precipitation was $299 \mathrm{~mm}$ on Mt. Yangming.

The rainfall intensity calculated by empirical equations for Taipei was $259.3 \mathrm{~mm} / \mathrm{h}$ and that for Mt. Yangming was $472.3 \mathrm{~mm} / \mathrm{h}$.

$$
\begin{aligned}
& \mathrm{I}_{1}=\mathrm{R}_{24} / 24[24 / \mathrm{t}]^{0.6}=164 / 24[24 / 0.056]^{0.6}=259.3 \mathrm{~mm} / \mathrm{h} \\
& \mathrm{I}_{2}=\mathrm{R}_{24} / 24[24 / \mathrm{t}]^{0.6}=299 / 24[24 / 0.056]^{0.6}=472.3 \mathrm{~mm} / \mathrm{h} \\
& \mathrm{t}=0.056 \mathrm{~h}(200 \mathrm{~s})
\end{aligned}
$$

where $\mathrm{I}$ is rainfall intensity per day; $\mathrm{R}$ is accumulated precipitation; $t$ is rainfall duration (hour or second); and $\mathrm{R}_{24}=164 \mathrm{~mm} /$ day for central Taipei city and $299 \mathrm{~mm} /$ day for Mt. Yangming.

The peak runoff for Taipei is $1.25 \mathrm{~cm}^{3} / \mathrm{s}\left(\mathrm{Q}_{1}\right)$ and for Mt. Yangming is $2.28 \mathrm{~cm}^{3} / \mathrm{s}\left(\mathrm{Q}_{2}\right)$.

$$
\begin{aligned}
& \mathrm{Q}_{1}=\mathrm{CIA} / 360=0.8 \times 259.3 \times 2.17 / 360=1.25 \mathrm{~cm}^{3} / \mathrm{s} \\
& \mathrm{Q}_{2}=\mathrm{CIA} / 360=0.8 \times 472.3 \times 2.17 / 360=2.28 \mathrm{~cm}^{3} / \mathrm{s}
\end{aligned}
$$

where

$-\mathrm{Q}=$ peak runoff $\left(\mathrm{cm}^{3} / \mathrm{s}\right)$

- $\mathrm{C}=$ rational method runoff coefficient

- I=rainfall intensity $(\mathrm{mm} / \mathrm{h})$

- A=catchments area, (ha)

Therefore, the peak runoff for Neihu area could be calculated as the averaged value of the two stations. The result is $1.77 \mathrm{~cm}^{3} / \mathrm{s}\left(\mathrm{Q}_{3}\right)$.

$$
\mathrm{Q}_{3}=(1.25+2.28) / 2=1.77 \mathrm{~cm}^{3} / \mathrm{s}
$$

The cross section of the drainage system on the western part of the platform was $0.5 \times 0.5 \mathrm{~m}$. The slope gradient is $33 \%$. So, the flow speed can be calculated by Manning's equation.

$$
\begin{aligned}
\mathrm{V} & =1 / \mathrm{n} \mathrm{R}^{2 / 3} \mathrm{~S}^{1 / 2}=1 / 0.025 \times 0.17^{2 / 3} \times 0.33^{1 / 2} \\
& =7.05 \mathrm{~m} / \mathrm{s}
\end{aligned}
$$

where $\mathrm{V}$ is flow speed $(\mathrm{m} / \mathrm{s}) ; \mathrm{n}$ is Manning resistance coefficient $\left(\mathrm{s} / \mathrm{m}^{1 / 3}\right)$; $\mathrm{R}$ is the hydraulic radius $(\mathrm{m})$; and $\mathrm{S}$ is the slope of the energy grade line (dimensionless).

$\mathrm{Q}_{\mathrm{S}}=\mathrm{AV}=0.5 \times 0.5 \times 7.05=1.76 \mathrm{~cm}^{3} / \mathrm{s}<\mathrm{Q}_{3}$

The estimated flow quantity is $1.76 \mathrm{~cm}^{3} / \mathrm{s}\left(\mathrm{Q}_{\mathrm{S}}\right)$ in the drainage system of the platform. However, the estimated peak $\left(\mathrm{Q}_{3}\right)$ is slightly larger than that $\left(\mathrm{Q}_{\mathrm{S}}\right)$ in the drainage system. This means that overflow could happen on the site. Besides, the drainage system appeared to have been blocked and not to have been maintained for several years, so the accumulated water could not properly flow through the drainage system at that time. 
Elevation (m)

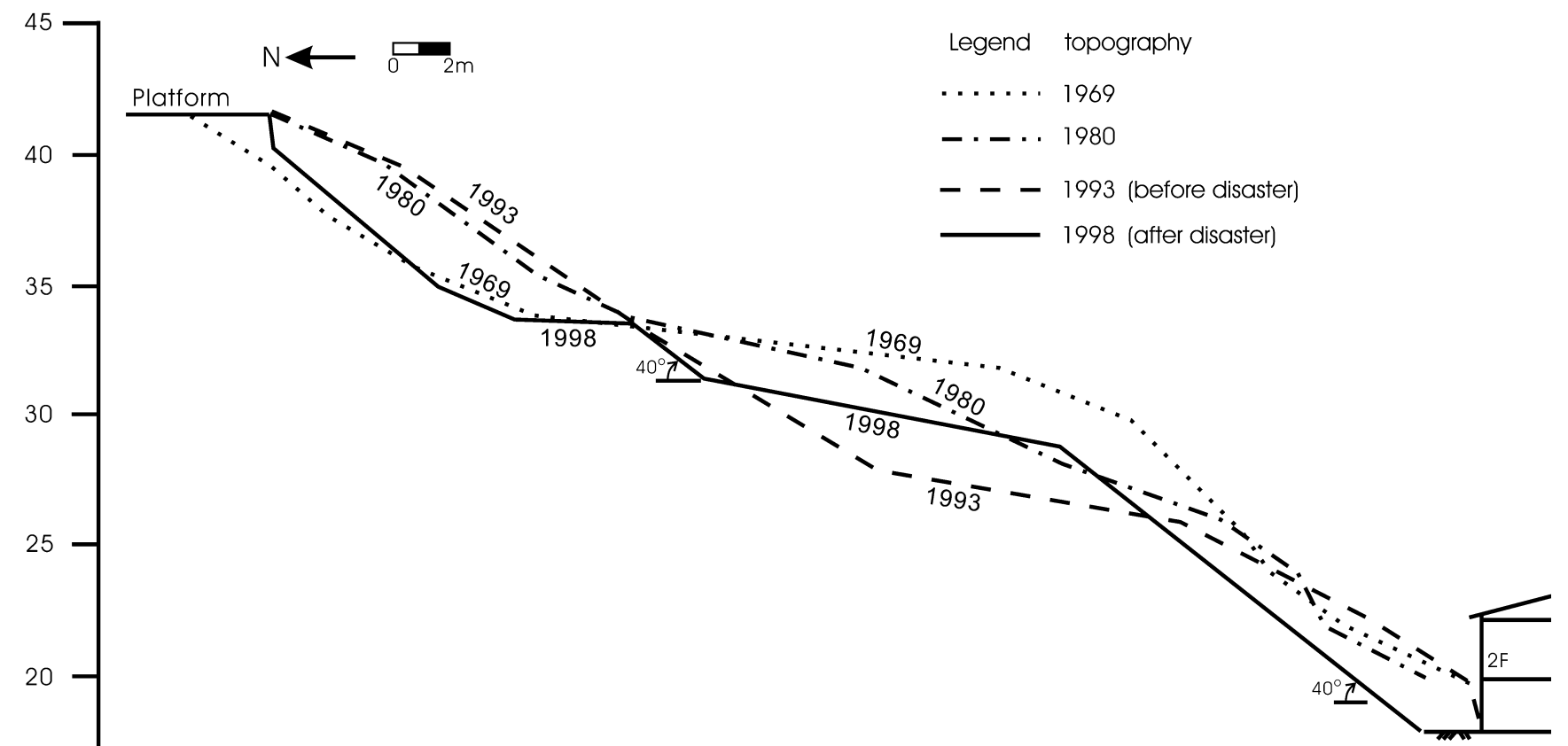

Fig. 6

The cross sections of morphology compositions at four different periods

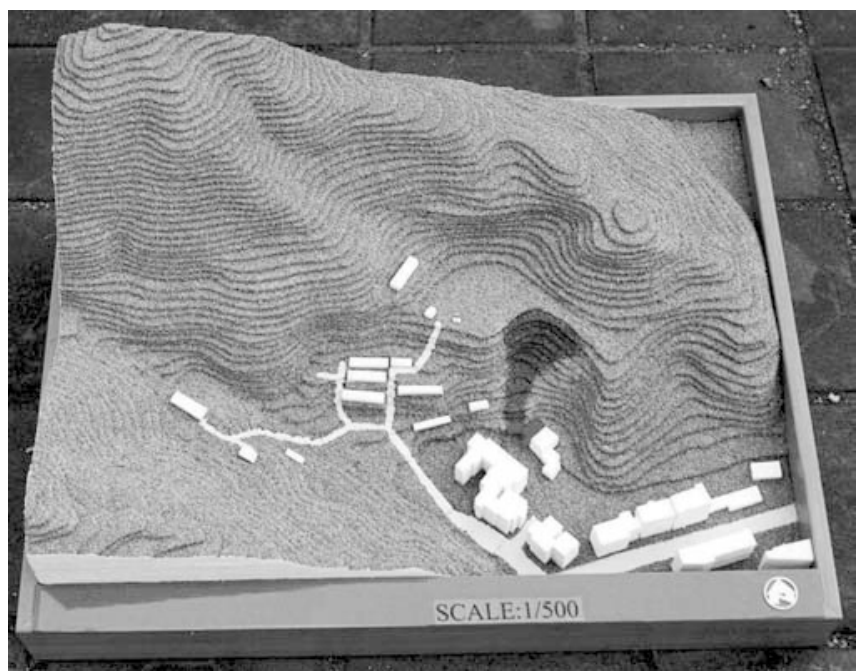

Fig. 7

The topography model displayed the environment of the disaster area

\section{Slope stability analysis}

The rainfall intensity $2.7 \times 10^{-4} \mathrm{~cm} / \mathrm{s}$ could be calculated from the above estimation. This value of rainfall intensity is much smaller than the coefficient of permeability in the topsoil of the study area. This also means that the surface waters, including rainfall and runoff, should have infiltrated into the ground surface easily.

Lumb (1962) proposed that a wetting front advances during heavy rainfall. During a rainfall exceeding the

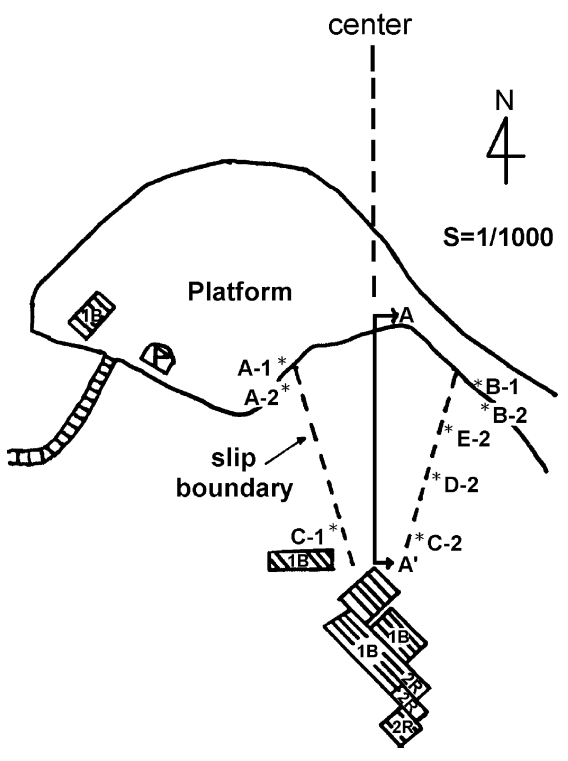

Fig. 8

The locations of the samples taken

infiltration capacity of the soil for time $t$, the front will advance to depth $\mathrm{h}$, as given by the following equation:

$$
\begin{aligned}
\mathrm{h}= & \mathrm{kt} / \mathrm{n}\left(\mathrm{Ss}_{\mathrm{f}}-\mathrm{S}_{\mathrm{i}}\right) \\
= & 2.7 \times 10^{-4} \mathrm{~cm} / \mathrm{s} \\
& \times(74 \mathrm{~h} \times 3,600 \mathrm{~s} / \mathrm{h}) / 0.463(0.98-0.81) \\
= & 9.0 \mathrm{~m}
\end{aligned}
$$

where $\mathrm{h}$ and $\mathrm{t}$ are defined previously, and

$-\mathrm{k}=$ rainfall intensity $(\mathrm{mm} / \mathrm{h})$

$-\mathrm{t}=$ rainfall duration (hour or second) 
Table 1

The geomaterial properties of study area

\begin{tabular}{|c|c|c|c|c|c|c|c|c|}
\hline Sample & $\begin{array}{c}\gamma_{\mathrm{sat}^{3}}(\mathrm{t} / \\
\left.\mathrm{m}^{3}\right)\end{array}$ & e & $\mathrm{n}$ & $\mathrm{Sr}(\%)$ & $\begin{array}{l}\mathrm{C}(\mathrm{kg} / \\
\left.\mathrm{cm}^{2}\right)\end{array}$ & $\Phi\left(^{\circ}\right)$ & $\begin{array}{l}\mathrm{c}^{\prime}(\mathrm{kg} / \\
\left.\mathrm{cm}^{2}\right)\end{array}$ & $\varphi^{\prime}\left(^{\circ}\right)$ \\
\hline A-1 & 1.91 & 0.86 & 0.46 & 80.7 & - & - & - & - \\
\hline A-2 & 1.99 & 0.69 & 0.40 & 74.9 & 0.05 & 25 & 0.03 & 31 \\
\hline B-2 & 1.98 & 0.70 & 0.41 & 72.4 & - & - & - & - \\
\hline D-2 & 2.03 & 0.63 & 0.39 & 74.0 & 0.06 & 30 & 0.03 & 32 \\
\hline E-2 & 2.00 & 0.70 & 0.41 & 73.9 & 0.06 & 24 & 0.02 & 31 \\
\hline
\end{tabular}

$\gamma_{\text {sat }}$ unit weight in saturated condition, $e$ void ratio, $n$ porosity, $S r$ degree of saturation, $c$ cohesion, $\varphi$ friction angle $-\mathrm{n}=$ porosity

$-\mathrm{S}_{\mathrm{f}}=$ final saturation

$-\mathrm{S}_{\mathrm{i}}=$ initial saturation

The result of $9.0 \mathrm{~m}$ depth in the above equation is valid only when the rainfall exceeds the infiltration capacity. However, a complicating factor is that the topsoil is not thick and the rock bed ranges from 1 to $4 \mathrm{~m}$ under the ground surface on the erosion gully. Thus, it is likely that the water would accumulate above the rock bed and the geomaterial would be fully saturated during heavy rainfall. In addition, the flow distance (d) can be calculated from the coefficient of permeability $(\mathrm{k})$ and slope angle (i) during the rainfall period $(t)$.

$$
\begin{aligned}
\mathrm{d}= & \mathrm{vt} \\
= & \mathrm{kit} / 2.0 \times 10^{-2} \mathrm{~cm} / \mathrm{s} \times \sin 30^{\circ} \\
& \times(74 \mathrm{~h} \times 3,600 \mathrm{~s} / \mathrm{h}) \\
= & 26.6 \mathrm{~m}
\end{aligned}
$$

The flow distance is estimated at $26.6 \mathrm{~m}$ by the above equation.

Analysis of slope stability (Graham 1984; Bromhead 1986) on the upper slope indicated a safety factor of 1.39 when the groundwater level was lower than the slip surface. The safety factor was 1.30 on the lower slope in the same condition. Hence, the whole slope should have been stable even when the groundwater level was deep. Precipitation that falls on the slope infiltrates into a saturated zone above the critical slip surface. Heavy rainfall will then cause increases in water content and water pressure that in turn lead to decreases in the shear strength of the slope-forming materials (Keefer and others 1984; Chen and others 1995). When the slope is fully saturated, the safety factor is 0.68 for the upper slope, and 0.64 for the lower slope. Thus, the slope becomes unstable state when saturated. In other words, there is a critical water pressure level on the developing slip surface past which the slope becomes unstable (Corominas 1996; Chen and others 1999). These results indicate that the safety factor is far below one, and that the slope would collapse when fully saturated.

\section{Failure processing}

The results of this investigation point to several conclusions about the study area. First, it was found that a small-scale failure occurred at the bottom of the erosion

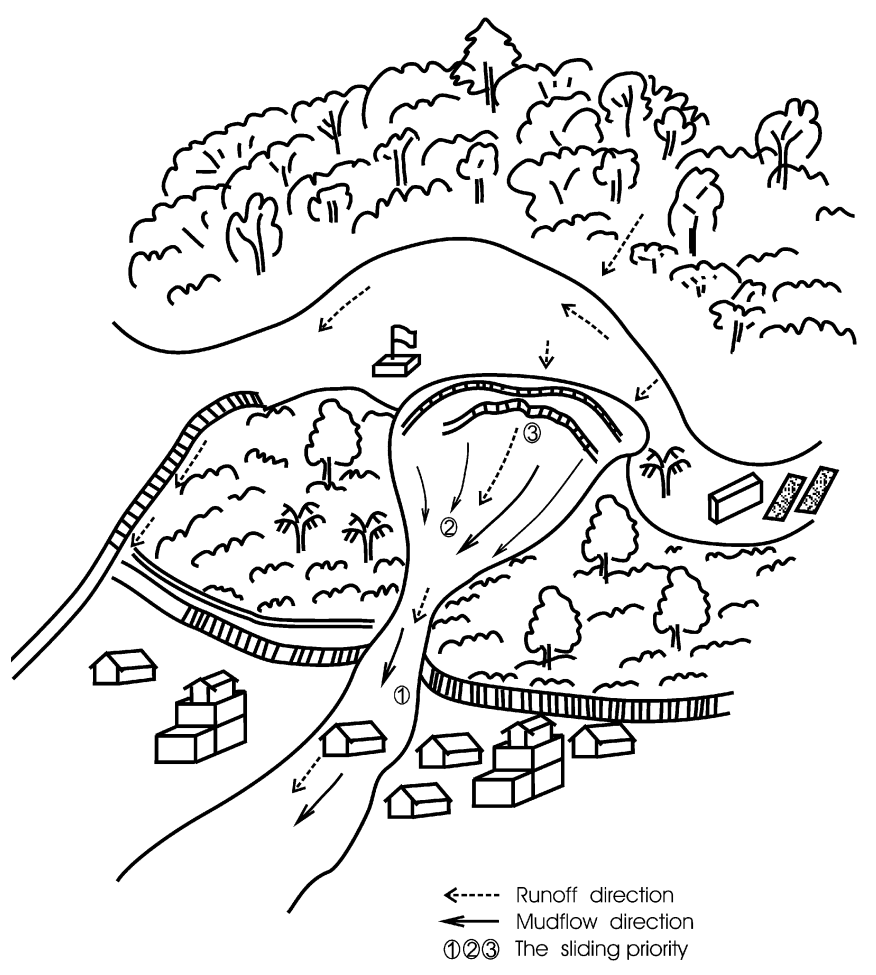

Fig. 9

Failure process simulated diagram of the study area

gully. Secondly, this initial failure triggered a retrogressive sliding in the middle part and then the upper part of the erosion gully (Fig. 9). The initial failure resulted from water accumulated from convergence of hydrological pathways along the catchments. Water was mixed with deposited material from the upper slope channel, which contributed to the transition of an initial landslide into a mudflow.

Initial movements of the mudflow certainly began with the runoff water, where prior rainfall spurred the origination of the mudflow by infiltrating into the hill slope of the study area. Movements accompanying an initial failure let the runoff water mix into the failed material, thus increasing the debris instability (Montgomery and others 2000; Marchi et al. 2002). The failure process proceeded like an upward denudation and kept progressing (Petley et al. 2002). Therefore, the front parts of the platform failed with massive surface water. Finally, it slid downward to the bottom of the gully and precipitated a serious disaster. 


\section{Discussion}

The mudflow hazard of the study area was not the result of one single factor. Comparison the relief maps of the area drawn up over time revealed changes in the topography. Dumped debris was identified to be the sliding material responsible for this mudflow hazard.

The empirical equation was simple and straightforward for the most part, and it was relatively easy to apply in this study area. The local landslide database required by the empirical method was readily available (Keefer and others 1984). The empirical equation provided an indication of the amount of storm precipitation that would induce a mudflow.

The typhoon delivered to this study area a rainfall intensity of $2.7 \times 10^{-4} \mathrm{~cm} / \mathrm{s}$. This value is smaller than the coefficient of permeability of the topsoil (about $10^{-3} \mathrm{~cm} / \mathrm{s}$ ). This means that the runoff on the ground surface normally could have infiltrated easily into the topsoil.

However, the rock bed of the erosion gully was shallow and fractured, so the water could be uplifted from below and infiltrate from the top into the slip zone $(\mathrm{Wu}$ and Swanston 1980; Johnson and Sita 1990). Consequently, the water pressure seemingly increased with increasing flow rate, particularly when the water was supplied from the bottom of the gully beds via rock joints (Chen and others 1999; Chen and Su 2001).

Hydraulic analysis estimated a peak runoff of $1.77 \mathrm{~cm}^{3} / \mathrm{s}$, which was slightly higher than the capacity of the drainage system. In addition, the drainage system had not been maintained for years and could not drain water effectively during heavy precipitation.

\section{Conclusions}

The mudflow hazard displayed the following features:

1. The topography of the erosion gully reflected a natural erosion phenomenon.

2. The weathered sandstone produced a higher permeability in the topsoil of the study area. Hence, the ground surface should allow a high absorption of rain -weathered sandstone makes up $20 \%$ of the topsoil.

3. The safety factor was less than 1.0 when the geomaterial was saturated because the erosion gully slope would be unstable when fully saturated.

4. The failure could be triggered from the bottom first and then retrogressed uphill rapidly under a massive precipitation context.

Acknowledgements Funding for this inspection project was provided by the Military Affairs Agency, Defence Ministry ROC. The experimental tests were executed in the Soil Mechanics Laboratory at Department of Civil Engineering of National Taiwan University. We are grateful to Mr. Y.L. Chu, the former
Director of Military Construction Agency, for help in the field survey and Ms. C.M. Yu in the article collection.

\section{References}

Bromhead EN (1986) The stability of slope. Surrey University Press, New York

Brundsden D (1984) Mudslides. In: Brunsden D, Prior DB (eds) Slope instability. Wiley, New York, pp 363-410

Chen H, Chen RH, Lin ML (1999) Initiation of the Tungmen debris flow, eastern Taiwan. Environ Eng Geosci V(4):459-473

Chen H, Su DY (2001) Geological factors for hazardous debris flow in Hoser, central Taiwan. Environ Geol 40:1114-1124

Chen RH, Lin ML, Chen H (1995) Mechanism of initiation of debris flow. In: Cheng FY, Sheu MS (eds) Urban disaster mitigation. Elsevier Science, Oxford, pp 231-243

Corominas J (1996) The angle of reach as a mobility index for small and large landslides. Can Geotech J 33:260-271

Cruden DM, Varnes DJ (1996) Landslide types and processes. In: Turner AK, Schuster RL (eds) Landslides: investigation and mitigation. Transportation Research Board, National Research Council, National Academy Press, Washington, DC, pp 36-75

Dai FC, Lee CF (2001) Frequency-volume relation and prediction of rainfall-induced landslides. Eng Geol 53:359-370

De Vita P, Reichenbach P (1998) Rainfall-triggered landslides: a reference list. Environ Geol 35(2-3):219-223

Graham J (1984) Methods of stability analysis. In: Brunsden D, Prior DB (eds) Slope instability. Wiley, New York, pp 171-215

Ho CS (1986) An introduction to the geology of Taiwan:

explanatory of the geologic map of Taiwan. The Ministry of Economic Affairs, Republic of China

Johnson AM, Rodine JR (1984) Debris flow. In: Brunsden D, Prior DB (eds) Slope instability. Wiley, New York, pp 257-361

Johnson AM, Sita N (1990) Hydrologic conditions leading to debris flow initiation. Can Geotech J 27(6):189-201

Keefer DK, Wilson RC, Mark RK, Brabb EE, Brown III WM, Ellen SD, Harp EL, Wieczorek GF, Alger CS, Zatkin RS (1984) Real-time landslide warning during heavy rainfall. Science 238:921-925

Leonards GA (1982) Investigation of failures. J Geotech Eng Div ASCE 108 (GT2):187-246

Lumb P (1962) Effect of rainstorms on slope stability. In: Pro Sym Hong Kong Soils, Hong Kong, pp 73-87

Marchi L, Arattano M, Deganutti AM (2002) Ten years of debrisflow monitoring in the Moscardo Torrent (Italian Alps). Geomorphology 46:1-17

Montgomery DR, Schmidt KM, Greenberg HM, Dietrich WE, (2000) Forest clearing and regional landsliding. Geology 28(4):311-314

Petley DN, Bulmer MH, Murphy W (2002) Patterns of movement in rotational and translational landslides. Geology 30(8):719722

Selby MJ (1993) Hillslope materials and processes. Oxford University Press, Oxford

Varnes DJ (1978) Slope movement types and processes. In: Schuster RL, Krizek RJ (eds) Landslides analyses and control. Nat Acad Sci Spec Rep 176:11-13

Wilson RC, Wieczorek GF (1995) Rainfall thresholds for the initiation of debris flow at La Honda, California. Environ Eng Geosci I(1):11-27

Wu TH, Swanston DN (1980) Risk of landslides in shallow soils and its relation to cutting in southeastern Alaska. Forest Sci 26(3):495-510 